\title{
CORRELATES OF DEPRESSION AMONG ELDERLY POPULATION RESIDING IN A COMMUNITY IN EASTERN NEPAL
}

\author{
Sharma $K R^{1 *}$, Yadav $B K^{1}$, Bhattachan $M^{2}$
}

\section{Affiliation}

1. Assistant Professor, School of Public Health \& Community Medicine, B.P. Koirala Institute Health Science, Dharan

2. Consultant $W H O$, Nepal

\section{ARTICLE INFO}

Article History

Received : 15 January, 2017

Accepted : 2 April, 2018

Published : 30 April, 2018

(C) Authors retain copyright and grant the journal right of first publication with the work simultaneously licensed under Creative Commons Attribution License CC - BY 4.0 that allows others to share the work with an acknowledgment of the work's authorship and initial publication in this journal.

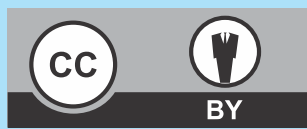

ORA 49

DOI: http://dx.doi.org/10.3126/bjhs.v3i1.19729

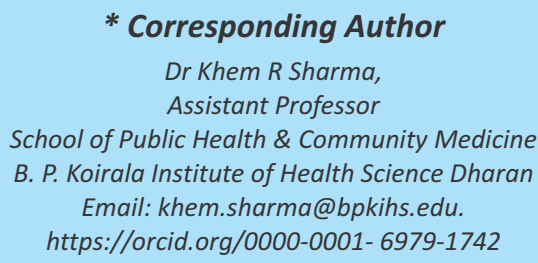

\section{Citation}

Sharma KR, Yadav BK, Bhattachan M. Correlates Of Depression Among Elderly Population Residing In A Community In Eastern Nepal. BJHS 2018;3(1)5:325-330.

\section{ABSTRACT}

\section{Introduction}

With a increase in life expectancy, demographic transition has led to sharp rise in number of elderly population. The elderly population growth rate per year has always been more than the total population growth rate, signifying the start of the ageing dynamics in Nepal. Mental health is a neglected health problem of the elderly in Nepal, with depression topping the list. This needs to be addressed in the national programs for the elderly to bring about an overall improvement in their health status.

\section{Objectives}

This study was conducted with objectives to identify the prevalence of depression and factors associated with it in an urban municipality of eastern Nepal.

\section{Methodology}

A community based cross-sectional study was conducted using the Geriatric Depression Scale- Short Form (GDS-SF) with 15 questions to screen for depression with a cutoff of 4/5. Door to door visit was done for data collection and face to face interviews were conducted. Pearson's Chi-square was used and Odds Ratio (OR) with confidence limits was calculated for inferential statistics. Logistic regression analysis was performed for all independent variables significantly associated in the bivariate analysis.

\section{Results}

Among the 353 study subjects interviewed, depression was identified in $65.2 \%$ by GDS-SF. Regression Model showed that age more than 70 years, being in the lower class of Kuppuswamy Socioeconomic scale and elderly who were not satisfied with the respect given by their community had more odds of being depressed.

\section{Conclusion}

Prevalence of depression among elderly was found to be very high in this study which was significantly associated with older age, low socio-economic status and perceived lack of respect from the community.

\section{KEYWORDS}

Geriatric, geriatric depression scale (GDS), mental health 


\section{INTRODUCTION}

Ageing is a normal phenomenon associated with physical, social and psychological changes. With declining fertility and mortality rates and rising life expectancy, demographic transition in the $21^{\text {st }}$ century has led to a sharp rise in number of older population. ${ }^{1}$ This increase has been noted in both developed and developing countries. ${ }^{2}$ It has been projected that $80 \%$ of older people will be residing in low and middle income countries by $2050 .^{3}$

The old age dependency rate calculated for different time periods shows an increasing trend from $7.5 \%$ in 1911 to $12.01 \%$ in 2001 . The elderly population growth rate per year has always been more than the total population growth rate in Nepal. ${ }^{4}$

With a rise in life expectancy, age structure of the population has been changing due to increase in proportion of people aged 60 years and above who constitute $8.4 \%$ of the population in Nepal. ${ }^{5}$ Though, the increase is not as high compared to those observed for developed countries (as high as 13\%), it signifies the start of the ageing dynamics in Nepal, that will have adverse effects on Nepalese social structure and economy in the long run.

Ageing is associated with various physiological and pathological changes including Mental Health. Mental health is a neglected health problem in Nepal, especially among elderly population. ${ }^{6}$ Limited researches have been conducted in the community as mental health ignites stigmatization, isolation and there have been lack of policies focusing on the needs of, and health measures provided for geriatric population in the health policies of Nepal.' Even the operational use of the existing policies regarding healthcare of elderly population has been virtually ignored by current health system. ${ }^{8}$ This study was conducted in one such representative urban area of Duhabi Municipality with objectives to identify the prevalence of depression and assess factors associated with depression among the geriatric population.

\section{METHODOLOGY}

A community based cross-sectional study was conducted among elderly population residing in Duhabi Municipality of Sunsari District over a duration of one month. This municipality is located in southeastern part of Sunsari district having a population of 25,545 with $5.75 \%$ elderly subjects ( $\geq 60$ years). ${ }^{5}$

The required sample size was calculated to be 353 based on the findings from the available literature, after adding for a non-response rate of $10 \% .{ }^{9}$ Data collection tools included a semi-structured questionnaire that was developed and pretested in Dharan Municipality on $10 \%$ of sample size, which was not included in the final analysis. The 15-item Geriatric Depression Scale (GDS) was translated into Nepali language, followed by back-translation by independent experts. GDS has been used in Asian communities for older adults and has been shown to have Cronbachs alpha of $0.80 .^{10}$ The score of 5 or above was used as cut-off for detecting depression as this cut-off has been reported to have a high sensitivity (92\%) and specificity (82\%). ${ }^{11}$
After obtaining data on the population composition of each ward of the municipality, the proportionate sample size for each ward was calculated. Data collection for the ward was started from the ward office and the direction was decided by rotating a bottle. Following this the first house was visited, and if an elderly was present, interview was conducted. The second house was skipped and collection was resumed in the third household. If there was no elderly in the household, data collection was resumed in the next household. This was continued till the required proportionate sample size for the ward was obtained.

In each household the nature and purpose of study was clearly explained and an informed written consent was obtained. One elderly from each household was included as respondent (study subject) irrespective of gender and where two or more were present, lottery was done to select one respondent. Each respondent was interviewed privately where s/he would feel comfortable to ensure privacy and confidentiality. Subjects absent at the time of visit were relayed information and asked to be present the next day to be assessed. Those absent even after this visit were excluded from the study.

Operational definition of a few terms used in this study have been included. Overcrowding was defined as less than 70 square feet of floor space area per person in the household. Floor space area refers to total floor space area of all the sleeping room in house divided by the number of family members. ${ }^{12}$ Pucca houses are made from high quality materials, i.e. bricks, cement, concrete, including roof, walls and floor while katcha houses are made from mud and thatch or other low quality materials. Semi-pucca houses are made from a combination of the above types..$^{13}$ Kuppuswamy socioeconomic score categories included lower socio-economic status defined as those having score of 0-10 andhigher socio-economic status as those having a score of $11-29 .^{14}$

Odds Ratio (OR) with confidence limit was calculated for inferential statistics. Logistic regression analysis was performed for all independent variables significantly associated in the bivariate analysis. This was done to identify associated factors for depression in elderly with the probability of significance set at $95 \%$ of Confidence Interval (CI).

Ethical permission was taken from the Institutional Review Committee (IRC) of BP Koirala Institute of Health Sciences before the study.

\section{RESULTS}

A total of 353 respondents aged 60 and above, residing in Duhabi Municipality participated in this study with a response rate of $94.13 \%$. Majority $(80.7 \%)$ of respondents belonged to age group of 60-70 years with a mean age of 66.4 years and standard deviation (SD) of 7.118. Among the participants, $81.6 \%$ were Hindu by religion and $59.2 \%$ Females. The Terai Janajati ethnicity (33.4\%) dominated other ethnic groups and $70.8 \%$ of the respondents were married. 


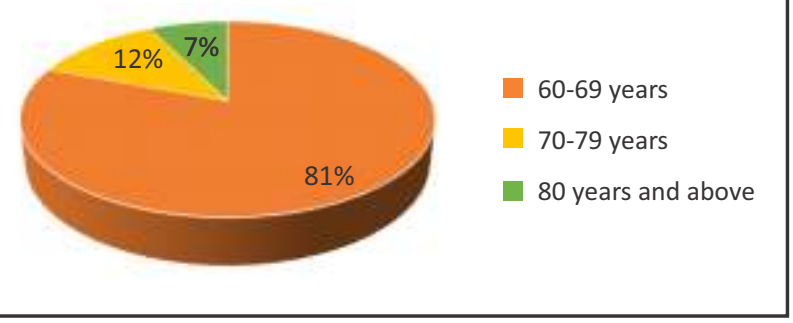

Figure 1: Age distribution of the study subjects $(n=353)$

About $64.9 \%$ of the respondents were illiterate and $68.3 \%$ unemployed. Only $57.5 \%$ of the respondents were in the normal BMI range. Based on the income, education and occupation status, majority $(60.6 \%)$ of households were in the Upper lower SES based on Kuppuswamy Scale as shown in Table 1.

Table 1. Socioeconomic and demographic profile of respondents residing in Duhabi Municipality $(n=353)$

\begin{tabular}{|c|c|c|c|}
\hline Characteristics & Categories & Frequency & Percentage \\
\hline \multirow[t]{2}{*}{ Sex } & Female & 209 & 59.2 \\
\hline & Male & 144 & 40.8 \\
\hline \multirow[t]{2}{*}{ Religion } & Hindu & 288 & 81.6 \\
\hline & Muslim & 64 & 18.1 \\
\hline \multirow[t]{8}{*}{ Ethnicity* } & Christian & 1 & 0.3 \\
\hline & Dalit Hill & 5 & 1.4 \\
\hline & Dalit Terai & 26 & 7.4 \\
\hline & Madhesi & 95 & 26.9 \\
\hline & Muslim & 64 & 18.1 \\
\hline & Janajati Hill & 7 & 2.0 \\
\hline & Janajati Terai & 118 & 33.4 \\
\hline & Brahmin/ Chettri & 38 & 10.8 \\
\hline \multirow{2}{*}{$\begin{array}{l}\text { Marital } \\
\text { status }\end{array}$} & Married & 250 & 70.8 \\
\hline & Divorced & 2 & 0.6 \\
\hline \multirow{7}{*}{$\begin{array}{l}\text { Body Mass } \\
\text { Index }\end{array}$} & Widowed & 101 & 28.6 \\
\hline & Underweight $(<18.5)$ & 31 & 8.8 \\
\hline & Normal (18.5-24.9) & 203 & 57.5 \\
\hline & Overweight (25-29.9) & 105 & 29.7 \\
\hline & Obese $(>30)$ & 14 & 4.0 \\
\hline & Upper-Middle & 31 & 8.8 \\
\hline & Lower-Middle & 80 & 22.7 \\
\hline \multirow{2}{*}{$\begin{array}{l}\text { Kuppuswamy } \\
\text { Scale }\end{array}$} & Upper Lower & 214 & 60.6 \\
\hline & Lower & 28 & 7.9 \\
\hline
\end{tabular}

\section{* Based on NDHS $2011^{5}$}

Among the respondents, a slightly greater percentage $(37.7 \%)$ lived in a Pucca house in comparison to katcha houses with overcrowding present in $61.8 \%$. Only $9.1 \%$ of the respondents did not use the toilet regularly. (Table 2 )

Among the respondents, only $66.3 \%$ still lived with spouse and children and $77.6 \%$ were satisfied with the respect they received from the community even in old age. Although 83.3\% had knowledge about the old age allowance provided by the government, only $23.5 \%$ were actually receiving it.

\begin{tabular}{|c|c|c|c|}
\hline Characteristics & Categories & Frequency & Percentage \\
\hline \multirow{3}{*}{$\begin{array}{l}\text { Type of } \\
\text { house }\end{array}$} & Katcha & 111 & 31.4 \\
\hline & Semi-pucca & 109 & 30.9 \\
\hline & Pucca & 133 & 37.7 \\
\hline \multirow{2}{*}{$\begin{array}{l}\text { Over } \\
\text { crowding }\end{array}$} & Yes & 218 & 61.8 \\
\hline & No & 135 & 38.2 \\
\hline \multirow{4}{*}{$\begin{array}{l}\text { Living } \\
\text { arrangement }\end{array}$} & Alone & 8 & 2.3 \\
\hline & With children & 92 & 26.1 \\
\hline & With spouse & 19 & 5.4 \\
\hline & $\begin{array}{l}\text { With spouse \& } \\
\text { children }\end{array}$ & 234 & 66.3 \\
\hline \multirow{3}{*}{$\begin{array}{l}\text { Get respect } \\
\text { from others }\end{array}$} & Satisfied & 274 & 77.6 \\
\hline & Sometimes avoided & 69 & 19.5 \\
\hline & Burden to family & 10 & 2.8 \\
\hline \multirow{2}{*}{$\begin{array}{l}\text { Knowledge } \\
\text { of old age } \\
\text { allowance }\end{array}$} & Yes & 294 & 83.3 \\
\hline & No & 59 & 16.7 \\
\hline \multirow{2}{*}{$\begin{array}{l}\text { Get } \\
\text { allowance }\end{array}$} & Yes & 83 & 23.5 \\
\hline & No & 270 & 76.5 \\
\hline
\end{tabular}

Table 3. Depression status among respondents residing in Duhabi Municipality using the Geriatric Depression Scale $(n=353)$

\begin{tabular}{|l|c|c|c|}
\hline Characteristics & \multicolumn{1}{|c|}{ Categories } & Frequency & Percentage \\
\hline $\begin{array}{l}\text { Geriatric } \\
\text { Depression } \\
\text { Scale }\end{array}$ & $<5$ (No Depression) & 123 & 34.8 \\
\cline { 2 - 4 } & $\geq 5$ (Depression) & 230 & 65.2 \\
\hline
\end{tabular}

Based on the Geriatric Depression Scale-Short Form, depression was seen among $65.2 \%$ of the respondents. (Table 3) Bivariate analysis with Pearson Chi-square showed that subjects aged seventy years or more were 2.4 times more likely to be depressed than subjects less than seventy years old $(p=0.006)$ and females had 1.8 times more chances of being depressed $(p=0.007)$. (Table 4) Similarly, not being married $(p=0.015)$, living in a Kutcha house $(p=0.010)$ and living without spouse $(p=0.028)$ were significantly associated statistically with being more depressed. Statistical association was highly significant $(p=0.000)$ for lower class elderly population based on Kuppuswamy socioeconomic scale and subjects not satisfied with the respect bestowed, with depression. 
Table 4. Bivariate Analysis ( $n=353)$

\begin{tabular}{|c|c|c|c|c|c|c|c|c|}
\hline \multirow{2}{*}{ Characteristic } & \multirow{2}{*}{ Category } & \multicolumn{2}{|c|}{$\begin{array}{l}\text { Geriatric Depression } \\
\text { Scale }\end{array}$} & \multirow{2}{*}{$\begin{array}{l}\text { Total } \\
(n=190)\end{array}$} & \multirow{2}{*}{ OR } & \multicolumn{2}{|c|}{$95 \% \mathrm{Cl}$} & \multirow{2}{*}{ Significance } \\
\hline & & $\begin{array}{c}\text { No } \\
\text { Depression }\end{array}$ & Depression & & & Lower & Upper & \\
\hline \multirow{2}{*}{ Age } & $<70$ years & 38.2 & 61.8 & 285 & 1.0 & & & \\
\hline & $\begin{array}{l}70 \text { years } \& \\
\text { above }\end{array}$ & 20.6 & 79.4 & 68 & 2.4 & 1.3 & 4.5 & 0.006 \\
\hline \multirow{2}{*}{ Gender } & Male & 43.1 & 56.9 & 144 & 1.0 & & & \\
\hline & Female & 29.2 & 70.8 & 209 & 1.8 & 1.2 & 2.9 & 0.007 \\
\hline \multirow{2}{*}{ Religion } & Others & 27.7 & 72.3 & 65 & 1.0 & & & \\
\hline & Hindu & 36.5 & 63.5 & 288 & 0.7 & 0.4 & 1.2 & 0.18 \\
\hline \multirow{2}{*}{$\begin{array}{l}\text { Marital } \\
\text { Status }\end{array}$} & Married & 38.8 & 61.2 & 250 & 1 & & & \\
\hline & Others & 25.2 & 74.8 & 103 & 1.9 & 1.1 & 3.1 & 0.015 \\
\hline \multirow{2}{*}{ BMI } & Normal & 37.9 & 62.1 & 203 & 1 & & & \\
\hline & Abnormal & 30.7 & 69.3 & 150 & 1.4 & 0.9 & 2.2 & 0.16 \\
\hline \multirow{2}{*}{$\begin{array}{l}\text { Kuppuswamy } \\
\text { Scale }\end{array}$} & Middle Class & 54.1 & 45.9 & 111 & 1 & & & \\
\hline & Lower Class & 26.0 & 74.0 & 242 & 3.3 & 2.1 & 5.3 & 0.000 \\
\hline \multirow{2}{*}{$\begin{array}{l}\text { Type of } \\
\text { House }\end{array}$} & Pucca/Semipuca & 39.3 & 60.7 & 242 & 1 & & & \\
\hline & Katcha & 25.2 & 74.8 & 111 & 1.9 & 1.2 & 3.2 & 0.010 \\
\hline \multirow{2}{*}{$\begin{array}{l}\text { Respect from } \\
\text { others }\end{array}$} & Satisfied & 40.9 & 59.1 & 274 & 1.0 & & & \\
\hline & Unsatisfied & 13.9 & 86.1 & 79 & 4.3 & 2.2 & 8.4 & 0.000 \\
\hline \multirow{2}{*}{ Living } & With Spouse & 38.3 & 61.7 & 253 & 1.0 & & & \\
\hline & Without Spouse & 26.0 & 74.0 & 100 & 1.8 & 1.1 & 2.9 & 0.028 \\
\hline \multirow{2}{*}{$\begin{array}{l}\text { Poverty } \\
\text { Status }\end{array}$} & Above & 40.2 & 59.8 & 102 & 1 & & & \\
\hline & Below & 32.7 & 67.3 & 251 & 1.4 & 0.9 & 2.2 & 0.18 \\
\hline
\end{tabular}

Table 5: Logistic Regression Analysis

\begin{tabular}{|c|c|c|c|c|c|}
\hline Characteristics & Category & $\begin{array}{l}\text { Adjusted OR } \\
\text { (aOR) }\end{array}$ & $\begin{array}{r}95 \% \\
\text { Lower }\end{array}$ & $\begin{array}{l}\text { Cl } \\
\text { Upper }\end{array}$ & $\begin{array}{l}\text { Significance } \\
\text { (p-value) }\end{array}$ \\
\hline \multirow[b]{2}{*}{ Age } & $<70$ years & 1 & & & \\
\hline & $\begin{array}{l}70 \text { years \& } \\
\text { above }\end{array}$ & 2.1 & 1.1 & 4.2 & 0.026 \\
\hline \multirow{2}{*}{$\begin{array}{l}\text { Kupuswamy } \\
\text { Scale }\end{array}$} & Middle Class & 1 & & & \\
\hline & Lower Class & 3.3 & 2.2 & 5.4 & 0.000 \\
\hline \multirow{2}{*}{$\begin{array}{l}\text { Respect from } \\
\text { others }\end{array}$} & Satisfied & 1 & & & \\
\hline & Unsatisfied & 4.2 & 2.1 & 8.4 & 0.000 \\
\hline
\end{tabular}

Goodness of fit: Chi-square $=0.892, d f=3, p=0.827$

Variable(s) entered on step 1: Age, Gender, Religion, Marital status, Kuppuswamy socioeconomic scale, Type of House, Get Respect from others and Living with/without Spouse.

Logistic regression analysis was used to assess the most significant factors associated with depression as identified by the Geriatric Depression Scale. After adjusting for other variables, age 70 years or more [adjusted $O R(a O R)=2.4$; $(1.2-4.7)]$, lower class category in the Kuppuswamy socioeconomic scale [aOR=3.0; (1.8-5.0)] and those not satisfied with the respect conferred by others [aOR=4.2; (2.0-8.7)] were significantly associated with depression.

\section{DISCUSSION}

The prevalence of depression among elderly in this study was $65.2 \%$ using the Geriatric Depression scale -15 , which is higher than that found by other studies conducted in community-dwelling elderly of three Asian countries (Indonesia: 33.8\%, Vietnam: 17.2\%, Japan: 30.3\%) and elderly of rural Thailand (27.5\%). ${ }^{9,15}$ Studies published in Nepal have also found high rates of depression among elderly ranging from $47.3 \%, 66 \%$ to $72.8 \%$ in old-age homes and $25.45 \%$ in community. ${ }^{16-19}$ This wide variation of prevalence could be attributed to various factors, firstly, the use of GDS-30 scale in some studies and the use of different cut-off values for GDS-15 scale and secondly, smaller sample sizes of studies in sheltered homes and hospitals giving varied prevalence. However, this study included an adequate sample size and used a cut-off of $4 / 5$ for the GDS15 which has a high sensitivity and specificity. ${ }^{11}$ The high prevalence of depression in this setting could be attributed to socio-cultural factors like lack of health care facilities pertaining to elderly population, migration of younger generation for employment and lack of awareness regarding mental illness. ${ }^{7}$ The migration of the younger population for employment to Arabian and other countries 
has left elderly population behind with no one to care for them. This could be one of the reasons for the high prevalence which needs to be studied further.

Variables that were significant in the bivariate analysis but not in the regression model were gender, marital status, type of house and living with/without spouse. Elderly female respondents were 1.8 times more likely to have depression than their male counterparts (OR=1.8, $\mathrm{Cl}: 1.2-2.9)$. Similar reports have been observed in studies conducted in Malaysia (OR $=2.87,95 \% \mathrm{Cl}: 1.37-6.02)$ and Pakistan (OR=3.5, $\mathrm{Cl}: 1.5-8.1$ ), where gender was a significant predictors for depression. ${ }^{2,20}$ In contrast, a few studies have not found gender to be a significant factor. ${ }^{15,21}$ Similarly in our study, gender was not significantly associated in the regression model.

A study showed that marital status had a direct role in predisposing the elderly to depression. ${ }^{22}$ In this study respondents who were unmarried/widowed/divorced were found to be 1.9 times likely to be depressed than those married $(\mathrm{OR}=1.9 ; \mathrm{Cl}: 1.1-3.1)$. However this was not significant in the regression model, similar to the findings of a study done in rural Malaysia. ${ }^{23}$

Poverty has been shown to be associated with depression in various studies including this. ${ }^{21}$ Poor housing conditions are present in underprivileged population that includes thatched houses, mud/wood walls which have been shown to be associated with depression in few studies, and was also observed in bivariate analysis in this study $(\mathrm{OR}=1.9 ; \mathrm{Cl}$ : 1.2-3.2). ${ }^{24}$ However, the regression model rendered this factor insignificant. Elderly population not living with their spouse were more likely to be depressed than those living with their spouse in the bivariate analysis in this study (OR=1.8; $\mathrm{Cl}: 1.1-2.9)$. This observation has also been seen in meta-analysis done by Yan et al $(\mathrm{OR}=1.55)$ and $\mathrm{Greece}$. $^{25,26}$

Among the findings significant in the regression model, this study showed that respondents aged 70 years or more were 2.1 times more likely to have depression than those less than 70 years of age (adjusted $\mathrm{OR}=2.1 ; \mathrm{Cl}: 1.1-4.2$ ), a finding that mirrors conclusions of other authors. ${ }^{27-29}$ However, few studies have not found any significant association of age with depression. ${ }^{15,16,19}$ The possible explanation could be that as a person grows older, the old age changes become more severe and incapacitating leading to social exclusion and mental disorders.

This study also shows that elderly in the Lower Class category of the Kuppuswamy scale were 3.3 times more likely to be depressed than their affluent counterparts (aOR=3.3; $\mathrm{Cl}: 2.0-5.4)$. This brings us to a point of view that being poor, lacking education and un/under-employment predisposes the elderly to depression as this scale is based on income, education and employment. ${ }^{14}$ This is in agreement with study carried out on elderly persons from two communities in Kingston, Jamaica. ${ }^{28}$ Other studies done in rural south Indian Community and rural Malaysia also showed that respondents with low income were at high risk for depression. ${ }^{21,23}$
Elderly who were satisfied by the respect they received from the community were less likely to be depressed in this study. Likewise those who were of the opinion that they were either avoided or perceived themselves as a burden to the family were 4.2 times at more odds of being depressed $(\mathrm{aOR}=4.2 ; \mathrm{Cl}: 2.1-8.4)$. This is in line with the findings of a study where Care Recipients who perceived that they were afforded lower levels of respect were at greater risk of depression and another dissertation from the Loyola University Chicago. ${ }^{30,31}$ Perceived respect from others is a positive support that keeps a person socially active and mobile. This study also identified this aspect which was statistically significant after adjusting for other variables.

\section{CONCLUSION}

Prevalence of depression among elderly was found to be very high in this study and is of a major concern, especially in this age of increased migration of the young of the household for employment, leaving the elderly behind. Depression was found to be associated significantly with age more than 70 years, low socio-economic status and perceived lack of respect for the elderly.

\section{RECOMMENDATIONS}

With the initiation of special health programs for the elderly by the government in Nepal, depression is also an important factor to be addressed in those programs as its prevalence is very high. Social Organizations also need to focus on the problem of the elderly and address them. The recent trend of migration for work is also partly responsible for the problem, for which long term solutions needs to be identified by the Government.

\section{LIMITATION OF THE STUDY}

Additional measures like routine lab investigations to assess the physical health would have provided a more comprehensive picture of the overall health of the elderly, but was not possible due to resource limitation. In addition, the study would have been more consistent if the scales used had been validated in the local population.

\section{ACKNOWLEDGEMENTS}

The authors would like to thank the elderly population of Municipality who participated in the research. The authors are also grateful to School of Public Health \& Community Medicine, BPKIHS for providing an opportunity to conduct the research. Last but not the least, the authors are indebted to Duhabi Municipality for their support.

\section{CONFLICT OF INTEREST}

None 


\section{REFERENCES}

1) Lalitha K. Health Aspects of Elderly: A Global Issue. Journal of Krishna Institute of Medical Sciences University.2012 JulyDec;1(2): 1-3. ISSN 2231-4261.

2) Sidik SM, Zulkefli NAM, Shah SA. Factors associated with depression among elderly patients in a primary health care clinic in Malaysia. Asia Pacific Family Medicine. 2003 Sep; 2(3):148-152. https://doi.org/10.1046/j.1444-1683.2003.00080.x.

3) WHO. Are you ready? What you need to know about ageing. Toolkit 2012 accessedon February 07, 2018, available from http:// www.who.int/world-health-day/2012/toolkit/background/en/.

4) Dhakal MR. Ageing and health in Nepal. Regional Health Forum. 2012; 16(1) available at http:/www.searo.who.int/publications/ journals/regional_health_forum/media/2012/rhf2012v16n1p12. pdf and accessed on 11/11/2017. ISSN 10204237.

5) Department of Health Services, Nepal. Nepal Demographic and Health Survey. 2011. available at http://dhsprogram.com/ pubs/ pdf/fr257\%5B13april2012\%5D.pdf and cited on 17/6/2017.

6) Shrestha SL. Validating the Center for Epidemiological Studies Depression Scale (Ces-D) for use among Older Adults in Nepal. University of Florida. accessed on 26/11/2017 and available at http://etd.fcla.edu/UF/UFE0005440/shrestha_s.pdf.

7) Bhattarai LPS. Older people's exclusion from healthcare services in Nepal: an analysis of the political economy of development aid, domestic policy and research. Geriatrics \& Gerontology International. 2013; 13(2): 243-9. https://doi.org/10.1111 /j.1447-0594.2012.00947.x.

8) Shrestha L. Geriatric Health in Nepal : Concerns and Experience. Nepal Medical College Journal. 2012; 15(2): 144-148.PMID: 24696938

9) Wada $T$, Ishine $M$, Sakagami $T$, Kita $T$, Okumiya $K$, Mizuno K,Matsubayashi K. Depression, activities of daily living, and quality of life of community-dwelling elderly in three Asian countries: Indonesia, Vietnam, and Japan. Archives of Gerontology and Geriatrics. 2005;41(3): 271-80.DOI: 10.1016/j.archger. 2005.03.003

10) Nyunt M, Fones $C$, Niti M, Ng TP. Criterion-based validity and reliability of the Geriatric Depression Screening Scale (GDS-15) in a large validation sample of community-living Asian older adults. Ageing and Mental Health. 2009 May; 13(3): 376-382.DOI: $10.1080 / 13607860902861027$.

11) Lyness JM, Noel TK, Cox C, King DA, Conwell Y, Caine ED. Screening for depression in elderly primary care patients - A comparison of the Center for Epidemiologic Studies-Depression Scale and the Geriatric Depression Scale. Arch Intern Med. 1997 Feb 24;157(4):449-54.PMID: 9046897.

12) Park K. Park's Text book of Preventive and Social Medicine. $20^{\text {th }}$ edition. Jabalpur: M/s BanarshidasBhanot;2009. 512p. ISBN: 97893822190579382219056.

13) Agrawal S.Effect of Living Arrangement on the Health Status of Elderly in India. Asian Population Studies. 2012; 8(1): 87-101. doi: 10.1080/17441730.2012.646842.

14) Ghosh A, Ghosh T.Modification of Kuppuswamy's Socioeconomic Status Scale in context to Nepal. Indian Pediatrics. 2009 Dec; 46: 1104-1105. PMID: 20061591.

15) Haseen F,Prasartkul P. Predictors of depression among older people living in rural areas of Thailand. Bangladesh Medical Research Council Bulletin. 2011; 37:51-56. PMID: 21877605.

16) Ranjan S, Bhattarai A, Dutta M. Prevalence of depression among elderly people living in old age home in the capital city Kathmandu. Health Renaissance 2013; 11(3): 213-218.DOI: http://dx.doi.org/ 10.3126/hren.v11i3.9634.
17) R Subba, HK Subba. Level of depression among elderly in selected old age homes at Manglore, India. Journal of Chitwan Medical College. 2015; 5(11): 28-32. http://dx.doi.org/10.3126/jcmc.v5i1. 12568.

18) Timilsina R, Sherpa PD, Dhakal DK. Factors associated with depression among elderly living in old age homes in Kathmandu Valley. Journal of Institute F Medicine.2014; 36(1): 90-96.

19) Ghimire H, Pokharel PK, Shyangwa PM, Baral DD, Aryal A, Mishra AK. Are Elderly People Living in Old-Age Home less depressed than those of Community ? Findings from a Comparative Study. Journal of Chitwan Medical College. 2012;1(2): 5-8.

20) Taqui AM, Itrat A, Qidwai W, Qadri Z. Depression in the elderly: does family system play a role? A cross-sectional study. BMC Psychiatry. 2007 Oct; 7: 57. DOI: 10.1186/1471-244X-7-57.

21) Rajkumar AP, ThangaduraiP, Senthilkumar $P$, Gayathri K, Prince $M$, Jacob KS. Nature, prevalence and factors associated with depression among the elderly in a rural south Indian community. Int Psychogeriatr. 2009 Apr;21(2):372-8. DOI: 10.1017/S104161 0209008527.

22) Goldman N, Korenman S, Weinstein R.Marital Status and Health among the Elderly. Social Science \& Medicine. 1995; 40(12): 1717-1730. PMID: 7660185

23) Rashid A, Manan A, Rohana A. Depression among the elderly Malays living in rural Malaysia. The Internet Journal of Public Health. 2010; 1(2): 1-10.

24) Krieger J, Higgins DL. Housing and Health : Time Again for Public Health Action. American Journal of Public Health. 2002; 92(5): 758-768. PMID: 11988443

25) Yan $X Y$, Huang $S M$, Huang $C Q, W u W H$, Qin $Y$. Marital status and risk for late life depression: a meta-analysis of the published literature. J Int Med Res. 2011;39(4):1142-54. DOI: 10.1177/147323001103 900402.

26) Argyropoulos $K$, Gourzis P, Jelastopulu E. Prevalence of depression among the elderly. Psychiatriki. 2012 Jan-Mar;23(1):39-45. PMID: 22549039

27) Ganguli M, Dube S, Johnston JM, Pandav R. Depressive Symptoms, Cognitive Impairment and Functional Impairment in a Rural Elderly Population in India : A Hindi Version of the Geriatric Depression Scale (GDS-H). International Journal of Geriatrics Psychiatry. 1999; 14: 807-820.

28) Gibson RC, Neita SM, Abel WD, James K, Gibson RC. Sociodemographic Factors Associated with Depressive Symptoms among Elderly Persons from Two Communities in Kingston, Jamaica. West Indian Medical Journal. 2013; 62(7): 615. DOI: 10.7727/wimj.2012.273.

29) de Oliveira SC, dos Santos AA, Pavarini SCL. The relationship between depressive symptoms and family functioning in institutionalized elderly.Rev Esc Enferm USP. 2014; 48(1):65-71. PMID: 24676110.

30) Wolff JL, Agree EM. Depression among Recipients of Informal Care: The Effects of Reciprocity, Respect, and Adequacy of Support. The Journals of Gerontology. 2004 May; Series B, 59(3): S173-S180. PMID: 15118023.

31) Kyungsoo $S$. The Effects of Acculturation, Health, Socioeconomic Status, and Perceived Respect on Older Adult Depression: Analysis of Korean American Older Adults in Chicago. Dissertation for Loyola University Chicago. 2013;Dissertation 689 accessed on 12/12/2017 and available at http://ecommons.luc. edu/luc diss/689. 